\title{
PENGARUH PH AWAL DAN DURASI PENAMBAHAN ALKALI PADA PENCELUPAN KAIN RAJUT BAMBU DAN KAPAS (60\%/40\%) MENGGUNAKAN ZAT WARNA REAKTIF VINIL SULFON METODA ONE-BATH
}

\author{
BAMBOO/COTTON (60\%/40\%) KNITTED MIXED FABRIC DYEING \\ WITH VINIL SULFON REACTIVE DYES IN ONE-BATH METHOD
}

\author{
Jonathan Hermawan, Samuel Martin Pradana, Rr Wiwiek Eka Mulyani* \\ Kimia Tekstil, Politeknik STTT Bandung, Bandung, 40272, Indonesia
}

*Alamat e-mail penulis korespondensi: wimulyani@gmail.com

Tanggal diterima: 24 Februari 2021; direvisi: 24 Maret 2021; disetujui terbit: 16 April 2021

\begin{abstract}
Abstrak
Kain rajut campuran bambu/kapas (60\%/40\%) dapat dicelup dengan zat warna reaktif Vinil Sulfon. Bambu serta kapas mempunyai perbandingan sifat daya serap yang dapat berpengaruh terhadap proses difusi serta penyerapan zat warna pada proses pencelupan. Pada penelitian ini membahas tentang pengaturan proses difusi pada pencelupan Bambu/kapas untuk mendapatkan kerataan warna yang baik. Laju difusi zat warna dan kerataan warna dipengaruhi oleh $\mathrm{pH}$ awal proses dan waktu penambahan alkali $\left(\mathrm{Na}_{2} \mathrm{CO}_{3}\right)$. Karakterisasi yang dilakukan terhadap hasil pencelupan dianalisa dengan pengujian K/S serta kerataan warna memakai spektrofotometer dan ketahanan luntur warna setelah pencucian. Hasil penelitian memperlihatkan bahwa kondisi $\mathrm{pH}$ awal pencelupan dan waktu penambahan alkali berpengaruh terhadap hasil pencelupan yang diamati. $\mathrm{pH}$ awal larutan dan waktu pemasukkan alkali yang optimum pada proses pencelupan kain Bambu/kapas metode one-bath adalah $\mathrm{pH}$ 7,5 dan waktu 10 menit dengan nilai ketuaan warna (K/S) 42,10 , kerataan warna (SD K/S) 1,2031 dan ketahanan luntur warna rata-rata $4-5$.

Keywords : Bambu, Kapas, Zat warna Reaktif Vinil Sulfon, pH, waktu penambahan alkali

\section{Abstract}

Knitted fabric made of Bamboo and Cotton (60\% / 40\%) can be dyed with Vinyl Sulfone reactive dye. The effect of the $\mathrm{pH}$ value and alkaline $\left(\mathrm{Na}_{2} \mathrm{CO}_{3}\right)$ expansion time were considered on the union coloring properties of the knitted mixed texture of Bambu/cotton. By measuring the $K / S$ values with a spectrophotometer, the union dyeing property of Bamboo/cotton was analyzed. The discoveries appeared that $\mathrm{pH}$ Conditions and alkaline addition time affected the dyeing properties of the union. The initial $\mathrm{pH}$ of the solution and the optimum time for alkalizing in the one-bath method of dyeing Bambu/cotton knitted fabric is $\mathrm{pH} 7.5$ and time of 10 minutes with a color aging value $(K / S)$ 42.10, evenness of color (SD K/S) 1.2031 and average color fastness 4 - 5.
\end{abstract}


Keywords : Bamboo, cotton, vinyl sulfone reactive dyes, $\mathrm{pH}$ Value, alkaline addition time

\section{PENDAHULUAN}

Serat Bambu merupakan serat selulosa regenerasi. Serat Bambu berasal dari pohon Bambu yang termasuk famili Gramineae (rumput). Tanaman ini mudah tumbuh terutama di daerah tropis disebut sebagai akar rimpang, yaitu sejenis buhul (rebung) yang bukan akar, maupun tandan'1.

Serat Bambu memiliki struktur yang khas, yaitu berbentuk kumparan, tipis, tajam di kedua sisinya, mengkilap di dua bagian permukaan sisinya, homogen, namun memiliki beberapa garis dangkal, permukaan seperti bentuk bulat, dengan sisi yang tidak merata ${ }^{2}$. Ada dua cara untuk memanfaatkan bambu di industri tekstil. Salah satunya adalah dengan memproduksi serat alami dari bambu dengan memberikan perlakuan fisika, dan kimia. Cara lain adalah dengan meregenerasi serat selulosa dengan memodifikasi supaya mirip seperti serat bambu. Menurut Ajay Rathod dan Avinash Kolhatkar (2010) , dalam jurnalnya menyatakan bahwa metode lain yang dilakukan dalam proses pembuatan serat bambu adalah dengan memuntir serat bambu yang diregenerasi setelah dibasahi menjadi bubur, seperti metode yang serupa dengan proses pembuatan rayon viskosa. Bubur pati dalam pembuatannya dihasilkan dari batang, dan daun bambu melalui proses hidrolisis oleh alkali, dan pemutihan dengan beberapa fasa ${ }^{3}$.

Serat bambu yang digunakan pada penelitian ini merupakan serat selulosa yang diregenerasi. Proses pembuatan untuk serat bambu yang diregenerasi menggunakan hidrolisisalkalisasi dengan prinsip pemutihan multifase meliputi proses berikut ini : Preparation, Steeping, Pressing,
Shredding, Ageing, Sulfurization, Xanthation, Dissolving, Spinning.

Proses pembuatan yang

disebutkan di atas menyerupai serat rayon viskosa, sehingga dapat disebut juga serat bambu viskosa.

Derajat kristalinitas bambu sebesar $52,54 \%$ sedangkan kapas sebesar 64,63\%2. Struktur amorf bambu sedikit lebih besar dibandingkan kapas sehingga Bambu mempunyai sifat penyerapan terhadap air serta daya serap terhadap zat warna lebih besar disbanding dengan kapas.

Moisture regain serat kapas pada keadaan standar ( $\mathrm{RH}$ 65\%) adalah 7$8,5 \%$ sebaliknya serat Bambu $13 \%$. Perbandingan daya serap ini akan mempengaruhi proses penyerapan zat warna pada proses pencelupan one bath ${ }^{4,5}$. Kain campuran Bambu/kapas dapat dicelup dengan zat warna reaktif vinil sulfon.

Zat warna reaktif vinil sulfon merupakan zat warna yang sangat popular dan merupakan kelas zat warna yang terlibat dalam reaksi adisi nukleofilik dengan serat selulosa. Weber dan Stickney (1993), menyebutkan bahwa Zat warna reaktif menunjukkan substantivitas, dan reaktivitas yang berbeda. Zat warna reaktif vinil sulfon (VS) memiliki reaktivitas yang lebih tinggi, daripada zat warna monoklorotriazin $(\mathrm{MCT})^{6}$. Vinil sulfon adalah grup reaktif yang mengalami reaksi adisi nukleofilik dengan serat kapas dalam kondisi alkali. Penambahan alkali dalam hal ini menyebabkan sulfato etil sulfon membentuk gugus vinil sulfonil yang bereaksi dengan kapas untuk menghasilkan ikatan serat dengan zat warna 4.

Serat yang dicelup dengan zat warna ini memiliki stabilitas penyimpanan yang sangat baik karena 
ikatan kimia antara vinil sulfon, dan serat selulosa sangat stabil terhadap hidrolisis asam. Zat warna ini memberikan tingkat perendaman, dan fiksasi yang tinggi, serta memiliki sifat ketahanan luntur terhadap pencucian yang baik $^{6}$. Substansi hasil sampingan dari zat warna vinil sulfon yang terhidrolisis pun rendah, sehingga pencucian akhir menjadi mudah ${ }^{7}$.

Dalam pencelupan kain campuran Bambu/kapas tidak hanya melibatkan pewarna reaktif tetapi juga penggunaan $\mathrm{pH}$ dan alkali. Menurut B. Ahmad, Burkinshaw dan Kabambe (2012) menjelaskan bahwa untuk pencelupan kain katun (selulosa), $\mathrm{pH}$ larutan zat warna, dan konsentrasi kesetimbangan ion selulosa akan meningkat sebagai hasil pembentukkan ikatan kovalen antara zat warna, dan kain kapas selulosa. ${ }^{8}$ Namun, karena persaingan ion. ion Sel-O, dan HO- dalam larutan zat warna pada $\mathrm{pH}$ tinggi, sebagian zat warna bereaksi dengan ion $\mathrm{HO}$-, ion selulosa pada serat menghasilkan reaksi hidrolisis. Penelitian Shangfei $\mathrm{Yu}$, dkk, 9 menunjukkan bahwa nilai $\mathrm{pH}$ adalah faktor utama yang mempengaruhi hidrolisis zat warna reaktif C.I. biru (zat warna tetap dalam bentuk sulfat atau vinil sulfon secara fundamental, tanpa reaksi hidrolisis). Ketika $\mathrm{pH}<11$, hidrolisis mulai terjadi, dan laju hidrolisis meningkat dengan meningkatnya $\mathrm{pH}$ ketika $\mathrm{pH}>11$.

Penelitian yang dilakukan oleh Gorjanc.,dkk menyebutkan pencelupan kapas dan bambu rayon dengan treatment menggunakan plasma dapat meningkatkan daya serap pada pencelupannya menggunakan ekstrak tanaman Fallopia japonica ${ }^{10}$. Gun dan Tiber meneliti tentang kekromatikan warna dan ketahanan luntur warna pada kain rajut bambu/kapas (50/50) yang dibandingkan dengan kain campuran viscose/kapas (50/50) dan modal/kapas (50/50) menggunakan zat warna reaktif pada pencelupan. Hasil yang didapat bahwa bambu/katun memiliki nilai ketuaan warna (K/S) dan nilai kekromatikan yang tinggi, tetapi memiliki nilai kecerahan (L) yang rendah. Namun ketahanan abrasi dan ketahanan luntur warna terhadap keringat lebih rendah dibandingkan kain viscose/kapas dan modal/kapas ${ }^{11}$. Bink.,dkk meneliti tentang pencelupan dan penyempurnaan bambu/kapas secara simultan penggunakan zat warna bejana dan reaktif dengan kecepatan pemasukan alkali diatur sebesar 40 $\mathrm{m} /$ menit. Hasil penelitian didapat dengan metoda tersebut dapat mengatasi kekusutan dan piling pada kain $^{12}$. Chaudhary.,dkk meneliti tentang analisi kekuatan warna dan ketahanan luntur warna pada kain campuran bambu'sutera dan cotton-sutera menggunakan zat warna reaktif. Hasil yang didapat pada penelitian tersebut adalah nilai ketuaan warna (K/S) bambu/sutera sedikit lebih tinggi dibandingkan kapas/sutera dan hasil ketahann gosok dan ketahanan terhadap cahaya untuk keduanya realatif baik.

Penelitian mengenai pengaruh waktu pemasukkan alkali (dopping time) pada pencelupan bambu/kapas masih agak jarang dilakukan. Hal tersebut memberikan peluang untuk dilakukan penelitian dalam mengatur proses pencelupan agar didapat kerataan warna hasil pencelupan pada bambu/kapas lebih rata (seragam) mengingat adanya perbedaan daya serap pada kedua jenis serat tersebut.

Alkali pada umumnya digunakan untuk menghasilkan anion selulosa nukleofilik yang cukup selama prosedur aplikasi pencelupan zat warna reaktif. Kondisi tersebut menimbulkan beberapa zat warna terhidrolisis, dan tidak dapat dihindari ${ }^{8}$. Alkali adalah faktor penting dalam fiksasi zat warna reaktif. Tetapi, semua zat warna reaktif tidak memiliki substantivitas, dan reaktivitas yang sama. Reaktivitas yang lebih tinggi dapat 
merusak pencelupan karena zat warna dapat terhidrolisis. Salah satu masalah utama dalam pencelupan dengan banyak zat warna reaktif yang tingkat fiksasinya yang rendah, seringkali kurang dari $70 \%$ zat warna yang bereaksi dengan serat. ${ }^{13}$

Pada pencelupan campuran kain Bambu/kapas, karena sifat Bambu yang memiliki daya serap yang tinggi, maka penggunaan konsentrasi garam yang tinggi akan meningkatkan laju penyerapan zat warna sehingga meningkatkan resiko pewarnaan yang tidak merata ${ }^{14}$. Adanya perbedaan karakteristik serapan antara Bambu dan kapas akan mempengaruhi proses difusi pada pencelupan metoda one bath, maka dilakukan penelitian mengenai penggunaan $\mathrm{pH}$ pada awal larutan 7,5; 8,5 dan waktu penambahan alkali natrium karbonat $\left(\mathrm{Na}_{2} \mathrm{CO}_{3}\right)$ bertahap yaitu $10,20,30,40$ menit untuk mengetahui pengaruh penambahan zat tersebut terhadap hasil pencelupan. Pengaturan $\mathrm{pH}$ awal larutan dimaksudkan untuk mengaktifkan zat warna vinil sulfon supaya mudah bermigrasi ke dalam serat. Pengaturan waktu pemasukkan alkali secara bertahap untuk membantu proses fiksasi zat warna pada serat agar mendapatkan kerataan warna yang baik.

Tujuan dari penelitian ini adalah menggunakan zat warna reaktif vinil sulfon dengan metode one-bath untuk mendapatkan hasil pencelupan yang merata pada kain campuran Bambu / kapas dengan kapasitas serap yang berbeda.

\section{BAHAN DAN METODA}

Kain yang digunakan dalam percobaan ini adalah campuran Bambu/Kapas $(60 \% / 40 \%)$ yang telah diberi perlakuan awal berupa proses scouring dan bleaching. Jenis kain rajut single jersey dengan ukuran benang $30 \mathrm{~S}$, cpi 30 helai/cm dan wpi 33 helai/cm. Zat warna reaktif vinil sulfon, zat pembasah, Zat anti sadah, Zat anti crease mark, natrium sulfat, natrium karbonat, asam asetat dan sabun non ionik.

Proses pencelupan dilakukan menggunakan metoda one-bath secara perendaman (exhaust) dengan perbandingan liquor ratio $1: 10$ pada suhu $60^{\circ} \mathrm{C}$ selama 45 menit dengan menggunakan mesin Jet Dyeing. Skema Proses Pencelupan dapat kita lihat pada gambar 1 berikut ini :

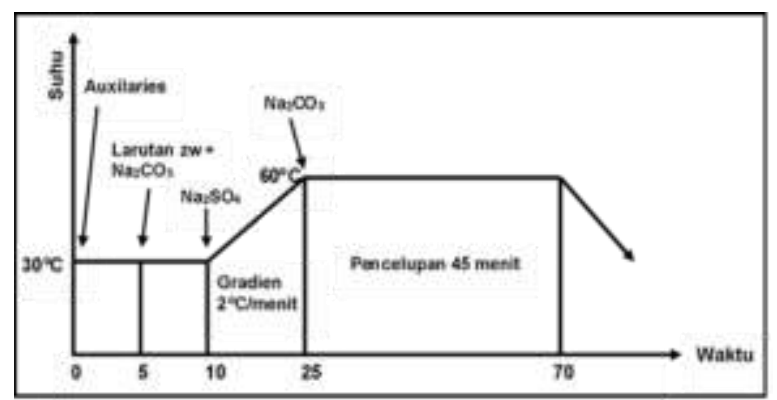

Gambar 1. Skema proses Pencelupan Bambu/Kapas (60/40\%) dengan Zat Warna Reaktif Vinil Sulfon metoda One-Bath.

Evaluasi dilakukan dengan menggunakan pengujian ketuaan warna dan kerataan warna berdasarkan SNI 08 - 4667 - 1998 memakai alat spektofotometer (Macbeth Color eye 3000) dari panjang gelombang $400-700$ $\mathrm{nm}$ menggunakan rentang $20 \mathrm{~nm}$, nilai reflektansi dikonversikan menjadi nilai ketuaan warna (K/S) dengan hukum Kubelka-Munk. Kerataan diperoleh dari nilai standar deviasi K/S. Pengujian ketahanan luntur warna dilakukan dengan studi literatur. 


\section{HASIL PENELITIAN}

Tabel 1. Hasil uji ketuaan warna kain pencelupan waktu alkali bertahap 10; 20; 30; 40 menit pada $\mathrm{pH}$ awal larutan 7,5 ;

\begin{tabular}{ccc}
\multicolumn{3}{c}{$\mathbf{8 , 5}$} \\
\hline Variasi & $\begin{array}{c}\text { K/S rata - rata dari masing - masing pH } \\
\mathbf{~ H H ~ 7 , 5}\end{array}$ & $\mathbf{p H ~ 8 , 5}$ \\
\hline 10 Menit & 42,10 & 39,89 \\
20 Menit & 40,305 & 40,80 \\
30 Menit & 41,275 & 44,46 \\
40 Menit & 38,635 & 36,77 \\
\hline
\end{tabular}

Tabel 2. Hasil uji kerataan warna kain pencelupan variasi $\mathrm{pH}$ awal larutan 7,5 ;

8,5 dan waktu alkali bertahap 10; 20 ; 30; 40 menit

\begin{tabular}{ccc}
\hline $\begin{array}{c}\text { Variasi } \\
\text { sampel }\end{array}$ & \multicolumn{2}{c}{ Standar Deviasi (SD) } \\
& $\mathbf{p H ~ 7 , 5}$ & $\mathbf{p H ~ 8 , 5}$ \\
\hline 10 menit & 1,2031 & 1,4826 \\
20 menit & 1,4772 & 1,8536 \\
30 menit & 0,9943 & 1,4136 \\
40 ment & 1,5742 & 1,3853 \\
\hline
\end{tabular}

Tabel 3. Penyandingan Ketahanan Luntur Zat Warna Vinil Sulfon Berdasarkan Literatur ${ }^{8}$

\begin{tabular}{|c|c|c|}
\hline \multirow{2}{*}{$\begin{array}{c}\text { Karakteristik Ketahanan } \\
\text { Luntur Warna }\end{array}$} & \multicolumn{2}{|c|}{ pH Pencelupan } \\
\hline & 8 & 9 \\
\hline $\begin{array}{l}\text { Ketahanan luntur } \\
\text { terhadap cahava }\end{array}$ & 4 & 5 \\
\hline $\begin{array}{l}\text { Ketahanan luntur } \\
\text { terhadap pencucian }\end{array}$ & 4 & 4-5 \\
\hline $\begin{array}{l}\text { Ketahanan luntur } \\
\text { terhadap dry cleaning }\end{array}$ & 4 & 4-5 \\
\hline $\begin{array}{l}\text { Ketahanan luntur warna } \\
\text { terhadap keringat }\end{array}$ & 4 & 4-5 \\
\hline $\begin{array}{l}\text { Ketahanan luntur warna } \\
\text { terhadap klorinasi }\end{array}$ & 4 & 4 \\
\hline $\begin{array}{c}\text { Ketahanan luntur dari } \\
\text { gosokan }\end{array}$ & 3-4 & 4 \\
\hline
\end{tabular}

Pada penelitian ini data ketahanan luntur warna untuk $\mathrm{pH}$ 7,5 dan 8,5 mengacu pada tabel nilai ketahanan luntur warna berdasarkan literatur diambil dari range antara $\mathrm{pH} 8$ dan 9 . Diasumsikan untuk nilai ketahanan luntur warna 7, 5 dan 8.5 sekitar 4 . Hal tersebut didasari karena pencelupan zat warna reaktif pada selulosa membentuk ikatan kovalen yang termasuk ikatan kimia yang paling kuat, sehingga memiliki nilai ketahanan luntur warna terhadap pencucian yang lebih tinggi di kisaran nilai 4 sampai 45.

\section{PEMBAHASAN}

\section{Ketuaan Warna}

Berikut adalah grafik yang menunjukkan hasil uji nilai ketuaan warna (K/S) dengan variasi $\mathrm{pH}$ awal larutan yang ditentukan pada nilai $\mathrm{pH}$ 7,$5 ; 8,5$, serta pemasukkan alkali bertahap yang divariasikan waktunya antara 10;20; 30; 40 menit.

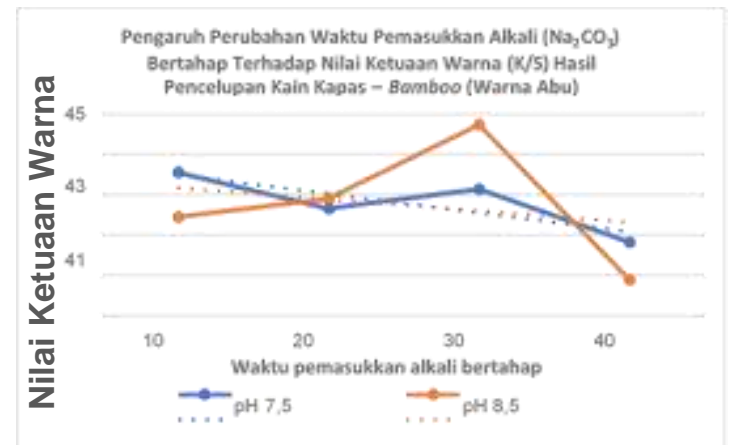

Gambar 2. Pengaruh perubahan waktu pemasukkan alkali $\left(\mathrm{Na}_{2} \mathrm{CO}_{3}\right)$ bertahap terhadap nilai ketuaan warna (K/S) hasil pencelupan kain Bambu - kapas (warna abu)

Pada serat bambu zat warna vinil sulfon akan reaktif jika ditambahkan alkali. Penambahan alkali pada awal selain berperan untuk mengaktifkan zat warna, berperan juga untuk menghambat laju difusi penyerapan zat warna ke dalam serat.

Fiksasi zat warna reaktif pada serat selulosa terjadi pada $\mathrm{pH}$ 10,5. Pada $\mathrm{pH}$ tersebut zat warna reaktif yang sudah terserap di dalam serat akan bereaksi dengan serat. Walaupun reaksi hidrolisis zat warna reaktif dengan air terjadi pada $\mathrm{pH}$ dan suhu yang tinggi, namun reaksi hidrolisis 
tersebut sangat sedikit kemungkinan terjadinya karena pada tahap awal telah dilakukan penambahan alkali dan pemasukkan alkali secara bertahap sehingga zat warna telah terserap kedalam serat. Selain itu sifat zat warna reaktif vinil sulfon yang tahan terhadap alkali dapat mengurangi reaksi hidrolisis.

Pengujian nilai ketuaan warna dilakukan dengan mengukur nilai K/S kain yang telah dicelup dari masing masing variasi. Semakin tinggi nilai $\mathrm{K} / \mathrm{S}$, menunjukkan ketuaan warna yang semakin tinggi. Dari Tabel 1 dan Grafik pada Gambar 2 tentang pengujian ketuaan warna, (nilai K/S) yang tertinggi pada waktu penambahan alkali bertahap yaitu pada waktu 10 menit, $\mathrm{pH}$ 7,5 dengan nilai $\mathrm{K} / \mathrm{S}$ sebesar 42,10. Untuk nilai $\mathrm{K} / \mathrm{S}$ terendah pada waktu penambahan alkali bertahap yaitu pada waktu 40 menit, $\mathrm{pH} 7,5$ dengan nilai $\mathrm{K} / \mathrm{S} 38,6350$

Oleh karena itu, penambahan alkali dilakukan pada tahap kedua setelah zat warna terserap oleh serat. Menurut Youssef jika semakin tinggi nilai $\mathrm{pH}$ pencelupan, maka menunjukkan tingkat substantivitas tinggi untuk kain selulosa pada nilai $\mathrm{pH}$ tinggi karena ikatan - ikatan kovalen antara zat warna, dan serat, khususnya zat warna reaktif berbasis vinil sulfon yang bekerja lebih baik pada $\mathrm{pH}$ alkali. Namun, jika diamati pada grafik titik waktu 10 menit, nilai $\mathrm{K} / \mathrm{S}$ variasi $\mathrm{pH}$ awal 8,5 memiliki nilai yang paling rendah jika dibandingkan dengan variasi lainnya. Hal ini berkaitan dengan faktor kerataan. jika tingkat substantivitas $\mathrm{pH} \quad 8,5$ lebih tinggi dibandingkan variasi lainnya. Variasi $\mathrm{pH}$ awal 7,5 memiliki rentang jarak antara hasil nilai ketuaan warna (K/S) terhadap perubahan waktu pemasukkan alkali yang lebih konstan, jika dilihat dari trendline grafik. Hal ini berkaitan dengan zat warna reaktif vinil sulfon pada $\mathrm{pH}$ alkali yang mendekati nilai netral 7 , dengan jumlah $-\mathrm{OH}$ yang lebih banyak dibandingkan $\mathrm{H}^{+}$, sehingga mengalami fiksasi terlebih dahulu sebelum terjadinya fiksasi secara keseluruhan tepat saat pemasukkan alkali untuk mencapai $\mathrm{pH}$ 10,5 - 11,0.

Reaksi antara zat warna reaktif, dan serat selulosa tidak mungkin terjadi tanpa alkali. Jumlah alkali adalah faktor penting dalam fiksasi zat warna reaktif. Tetapi, semua zat warna reaktif tidak memiliki substantivitas, dan reaktivitas yang sama. Reaktivitas yang lebih tinggi dapat merusak pencelupan karena zat warna dapat terhidrolisis.

Reaksi fiksasi yang terjadi antara zat warna dengan serat dapat kita perhatikan pada Gambar 3. di bawah ini :

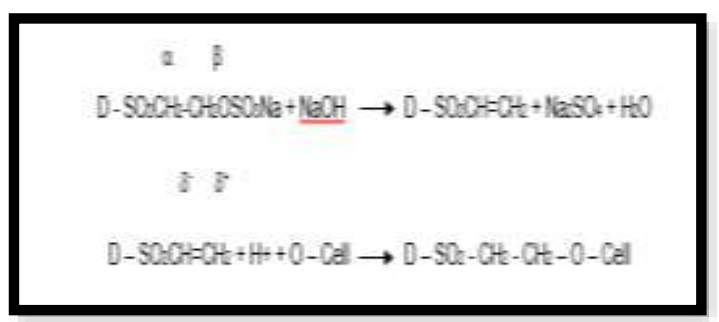

Gambar 3. Reaksi Fiksasi Zat warna Reaktif dengan serat selulosa (sumitomo chemical)

Reaksi yang terbentuk pada gambar tersebut merupakan reaksi fiksasi antara zat warna dengan serat selulosa, didalam proses fiksasi, alkali yang terdapat pada zat warna akan bereaksi pada serat selulosa serta melepaskan ion $\mathrm{H}^{+}$sehingga tersisa cell - o yang akan berikatan dengan zat warna dengan melepas ion $\mathrm{O}^{-}$sehingga terbentuk ikatan kovalen pada serat selulosa dengan zat warna yang menyebabkan tahan luntur yang dihasilkan setelah pencelupan menjadi baik.

Hasil penelitian menunjukkan bahwa semakin lama waktu penambahan alkali $\left(\mathrm{Na}_{2} \mathrm{CO}_{3}\right)$, memberikan nilai ketuaan warna yang 
semakin rendah. Hal ini disebabkan karena semakin lama jarak waktu penambahan alkali, maka waktu fiksasi yang terjadi dalam pencelupan akan semakin sedikit, sehingga, zat warna yang berikatan secara kovalen dengan serat bambu/kapas menjadi sedikit. Jika semakin tinggi waktu perendaman, maka sensitivitas waktu perendaman pada fiksasi zat warna vinil sulfon melaju dari sedang menuju rendah namun semakin tinggi waktu fiksasi, maka sensitivitas waktu fiksasi tidak berubah, dan hal ini menunjukkan bahwa zat warna vinil sulfon sangat sensitif terhadap waktu fiksasi, walaupun diperlukan waktu yang sedikit ${ }^{15}$.

Secara umum mekanisme proses pencelupan zat warna reaktif pada kain selulosa dibagi kedalam dua fasa penting yaitu fasa adsoprsi dan fasa difusi serta fasa fiksasi. Fasa adsopsi dan difusi terjadi ketika zat warna teradsoprsi ke permukaan serat dan berdifusi ke dalam matrix serat. Sedangkan fasa fiksasi terjadi ketika anion zat warna dan serat saling bereaksi. Pengaturan laju difusi dengan $\mathrm{pH}$ awal larutan di $\mathrm{pH}$ alkali dan penambahan alkali secara bertahap dapat membantu migrasi zat warna, penyerapan dan fiksasi zat warna dari permukaan serat ke dalam serat secara merata.

Perihal jarak waktu pemasukkan alkali bertahap 40 menit untuk fiksasi zat warna menyeluruh tidak dianjurkan karena akan sangat mempengaruhi terjadinya banyak zat warna vinil sulfon yang terhidrolisis akibat temperatur yang tinggi, dan unsur $\mathrm{H}^{+}$di dalam air. Hal tersebut menyebabkan warna hasil pencelupan menjadi tidak maksimal. Sebaliknya, pemasukkan alkali pada waktu 10 menit memiliki nilai ketuaan warna (K/S) yang tinggi. Hal tersebut relevan dengan teori yang menjelaskan pewarnaan reaktif menggunakan zat warna vinil sulfon sangat sensitive terhadap waktu. Semakin sedikit waktu pemasukkan alkali, maka akan memperpanjang waktu fiksasi selama pencelupan berlangsung, dimana gugus sulfatoetilsulfon akan bereaksi dengan alkali membentuk gugus vinil sulfon yang larut dalam air, dan mudah berdifusi ke dalam serat, serta pada akhirnya akan terfiksasi lebih banyak.

Dengan adanya penambahan alkali secara bertahap akan mengakibatkan reaksi fiksasi berjalan lebih lambat sehingga warna hasil pencelupan yang dihasilkan menjadi lebih rata.

Struktur amorf dan moisture regain pada serat Bambu (13\%) mempengaruhi laju penyerapan dan proses penyerapan zat warna. Strukturnya yang tidak kompak, dan tidak sejajar menyebabkan fleksibilitas dan porositas sehingga air maupun larutan zat warna akan lebih mudah mengisi celah-celah kosong dan lebih mudah menyerap. Struktur amorf yang dimiliki serat modals lebih banyak dibandingkan kapas, sehingga Bambu dapat menyerap zat warna lebih mudah dibandingkan kapas. Dari pemaparan tersebut dapat kita lihat bahwa sifat serat sangat berpengaruh terhadap sifat pencelupa nya, sehingga proses difusi zat warna sangat dipengaruhi oleh sifat amorf dan kristalin suatu serat ${ }^{2}$.

\section{Kerataan warna hasil pencelupan}

Tujuan pencelupan adalah mendapatkan warna yang rata di seluruh permukaan kain. Kerataan warna diuji dengan menggunakan spektrofotometer pada rentang gelombang 400-700 nm. Nilai kerataan warna ditunjukkan dengan nilai standar deviasi dari data K/S. Grafik di bawah ini menunjukkan hubungan antara pengaruh antara ph awal 7.5 dan 8.5 dan waktu pemasukkan alkali secara bertahap antara 10; 20; 30; 40 menit. 


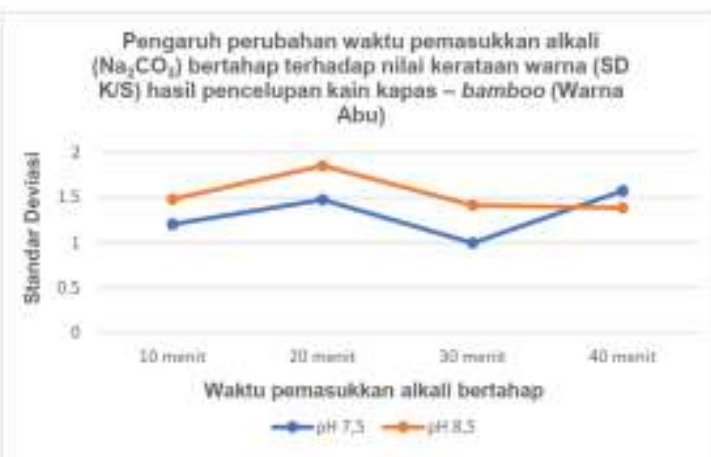

Gambar 3. Hubungan Konsentrasi Natrium Sulfat dengan Natrium Karbonat terhadap Kerataan warna

Nilai standard deviasi dari data nilai $\mathrm{K} / \mathrm{S}$ di hitung untuk mengevaluasi kerataan warna hasil pencelupan. Semakin rendah nilai standar deviasi, menunjukkan kerataan warna yang semakin baik. Dari hasil pengujian yang dilakukan yang ditunjukkan pada Tabel 3.dan Grafik pada gambar 4. nilai standar variasi yang terendah berada pada waktu penambahan alkali 30 menit, dengan nilai $\mathrm{pH} 7,5$ yang memberikan nilai sebesar 0.9943 sedangkan untuk variasi lainnya memperoleh nilai standar deviasi yang cukup tinggi. Dari data tersebut menunjukkan bahwa penambahan alkali dapat memperbesar migrasi zat warna ke dalam serat. Namun penambahan alkali yang lebih sedikit akan mengakibatkan reaksi fiksasi berjalan lebih lambat sehingga warna hasil pencelupan menjadi lebih rata.

\section{Ketahanan Luntur Warna Terhadap Pencucian}

Pengujian ketahanan luntur warna pada hasil penelitian ini tidak dapat dilakukan secara eksperiment mengingat masa pandemic covid-19 yang membatasi waktu dan tempat untuk dilakukan uji. Ketahanan luntur warna dari hasil pencelupan variasi $\mathrm{pH}$ awal, dan waktu pemasukkan alkali Natrium Karbonat $\left(\mathrm{Na}_{2} \mathrm{CO}_{3}\right)$ akan dibahas secara berdasarkan literatur yang terkait. Faktor utama dari ketahanan luntur warna adalah kekuatan ikatan antara serat dengan zat warna. Ikatan antara Serat Bambu/kapas dengan zat warna reaktif vinil sulfon membentuk ikatan kovalen. Ikatan ini temasuk ikatan yang kuat dalam ikatan kimia. Zat warna yang terhidrolisis dapat dihilangkan pada proses pencucian. Pencelupan zat warna vinil sulfon terjadi reaksi bolak balik sehingga sebelum dilakukan pencucian dilakukan penetralan menggunakan asam asetat.

$\mathrm{pH}$ larutan selain berfungsi untuk mengaktifkan zat warna vinil sulfon berfungsi pula sebagai penyeimbang zat warna untuk bermigrasi di bagian amorf serat. Serat bambu memiliki bagian amorf lebih banyak daripada kapas, sehingga migrasi zat warna akan lebih banyak ke serat bambu yang dapat menyebabkan serat bambu terwarnai lebih tua dibandingkan kapas. Pengaturan $\mathrm{pH}$ awal larutan dan pemasukkan alkali bertahap berperan sebagai penghambat laju difusi zat warna pada serat campuran yang memiliki perbedaan daya serap cukup tinggi. Berdasarkan literatur moisture regain bambu sebesar $13 \%$ sedangkan kapas sebesar $8 \%$.

Faktor $\mathrm{pH}$ awal pencelupan juga mempengaruhi ketahanan luntur warna, seperti yang tercantum pada literatur Tabel 3. Berdasarkan literatur tersebut menunjukkan bahwa semakin besar $\mathrm{pH}$ di awal pencelupan yang dilakukan, maka akan meningkatkan nilai ketahanan luntur warnanya, mencapai titik maksimum pada $\mathrm{pH}$ 9. Data penelitian yang diujikan menggunakan variasi $\mathrm{pH}$ awal 7,5 , dan 8,5 dapat dikategorikan ke dalam data tabel literatur karena memiliki nilai yang sangat mendekati, dimana $\mathrm{pH} 7,5$ diasumsikan sebagai $\mathrm{pH}$ 8, dan $\mathrm{pH} 8,5$ diasumsikan sebagai $\mathrm{pH} 9$. 


\section{KESIMPULAN}

Waktu pemasukkan alkali bertahap berpengaruh terhadap ketuaan warna, kerataan warna, dan ketahanan luntur warna terhadap pencucian. Hasil penelitian pada variasi $\mathrm{pH}$ awal 7,5 dengan waktu pemasukkan alkali 30 menit menunjukkan hasil yang optimum berdasarkan hasil pengujian ketuaan dan kerataan warna. 


\section{DAFTAR PUSTAKA}

1. Liu, L., Wang, Q., Cheng, L., Qian, J. \& Yu, J. Modification of natural bamboo fibers for textile applications. Fibers Polym. 12, 95-103 (2011).

2. Yueping, W. et al. Structures of Bamboo Fiber for Textiles. Text. Res. J. 80, 334-343 (2010).

3. A. R. Analysis of Physical Characteristics of Bamboo Fabrics. Int. J. Res. Eng. Technol. 03, 21-25 (2014).

4. Bairagi, N., Gulrajani, M. L., Deopura, B. L. \& Shrivastava, A. Dyeing of Nmodified viscose rayon fibres with reactive dyes. Color. Technol. 121, 113-120 (2005).

5. El-Shishtawy, R. M., Youssef, Y. A., Ahmed, N. S. E. \& Mousa, A. A. The use of sodium edate in dyeing: II. Union dyeing of cotton/wool blend with hetero bifunctional reactive dyes. Dye. Pigment. 72, 57-65 (2007).

6. Weber, E. J. \& Stickney, V. C. Hydrolysis kinetics of Reactive Blue 19-Vinyl Sulfone. Water Res. 27, 63-67 (1993).

7. Siddiqua, U. H., Ali, S., Iqbal, M. \& Hussain, T. Relationship between structure and dyeing properties of reactive dyes for cotton dyeing. J. Mol. Liq. 241, 839844 (2017).

8. Ahmad, B. Synthesis and Applications of Three Vinylsulfone Based Fiberreactive azo Dyes for Dyeing Cotton Fabric. Int. J. Basic Appl. Sci. 12, 129-136 (2012).

9. Zhang, K. et al. Effects of reactive dye structures on surface tensions and viscosities of dye solutions. J. Mol. Liq. 287, 110932 (2019).

10. Gorjanc, M. et al. Dyeing of plasma treated cotton and bamboo rayon with Fallopia japonica extract. Cellulose 23, 2221-2228 (2016).

11. Gun, A. D. \& Tiber, B. Color, color fastness and abrasion properties of 50/50 bamboo/cotton blended plain knitted fabrics in three different stitch lengths. Text. Res. J. 81, 1903-1915 (2011).

12. SUN, B., JIA, J. W., WU, S. C., \& CUI, H. W. (2005)... - Google Cendekia. https://scholar.google.com/scholar?hl=id\&as_sdt=0\%2C5\&q=SUN\%2C+B.\%2C $+\mathrm{JIA} \% 2 \mathrm{C}+\mathrm{J} .+\mathrm{W} . \% 2 \mathrm{C}+\mathrm{WU} \% 2 \mathrm{C}+\mathrm{S} .+\mathrm{C} . \% 2 \mathrm{C}+\% 26+\mathrm{CUI} \% 2 \mathrm{C}+\mathrm{H} .+\mathrm{W} .+\% 282005$ $\% 29 .+$ Dyeing+and+finishing+of+bamboo\%2Fcotton+blended+fabric+\%5BJ\%5 D. + Dyeing+and+Finishing $\% 2 \mathrm{C}+6 . \&$ btnG $=$.

13. . A. N. M. A. H. Effect of Dyeing Parameters on Dyeing of Cotton Fabrics With Fluoro Chloro Pyrimidene Reactive Dyes. Int. J. Res. Eng. Technol. 03, 125128 (2014).

14. Azeem, M. W., Hanif, M. A. \& Khan, M. M. Bamboo. Med. Plants South Asia 29-45 (2020) doi:10.1016/b978-0-08-102659-5.00003-3.

15. Sanjida Sultana 2016 reactive dye vinyl sulfone - Google Cendekia. https://scholar.google.com/scholar?hl=id\&as_sdt=0\%2C5\&q=Sanjida+Sultana+ 2016+reactive+dye+vinil+sulfon\&btnG=. 